\title{
REVIEW OF ENHANCEMENT IN HEAT TRANSFER RATE USING NANOFLUIDS OF HELICALLY COILED TUBE HEAT EXCHANGER
}

\author{
Amol F. Niwalkar ${ }^{1}$ and Jagdeep M. Kshirsagar ${ }^{2}$
}

\begin{abstract}
Helically coiled heat exchangers are globally used in various industrial applications for their high heat transfer performance and compact size. Nanofluids can provide the excellent thermal performance of this type of heat exchangers. Research studies on heat transfer enhancement have gained serious momentum during recent years and have been proposed many techniques by different research groups [1]. Normally heat transfer fluids have a low thermal conductivity that mainly affects the heat exchanger efficiency. A fluid with higher thermal conductivity has been developed to increase the efficiency of heat exchangers. The dispersion of $1-100 \mathrm{~nm}$ sized solid nanoparticles in the traditional heat transfer fluids, termed as nanofluids, exhibit substantial higher convective heat transfer than that of traditional heat transfer fluids. Nanofluid is a heat transfer fluid which is the combination of nanoparticles and base fluid that can improve the performance of heat exchanger systems. In this present paper the efforts are made to understand that how to enhance the heat transfer rate in helically coiled tube heat exchangers using different nanofluids by studying research papers of various authors. The authors used different nanoparticles for their research work and compared the enhancement in heat transfer coefficient is with distilled water with different concentrations of nanofluids. In this paper, the preparation of nanofluid and the steps to prepare nanofluid is interpolated with the equations for heat transfer coefficient. The effect of nanofluids and their shape and size on friction factor, pressure drop and pumping power are subsumed in this study.
\end{abstract}

Keywords - Nanofluid, Nanoparticles, Heat Exchanger, Convective Heat Transfer, Heat Transfer Coefficient

\section{INTRODUCTION}

Heat exchangers are universally used in different engineering applications for example, in food and chemical industry, power generation, automobile sector, waste heat recovery, refrigeration and air conditioning. Now a day's different industry are motivated to employ energy saving policy as much as feasible in their abilities due to the high cost of energy. In recent decennium, efforts have been done to increase heat transfer of different heat exchangers, minimize the heat transfer time and lastly try to make effectively utilize the energy with higher efficiency. Usually these efforts involve active, passive and compound methods such as extending the heat exchanger surface area or use such fluid those have high thermo physical properties, and can create turbulence [1].

\footnotetext{
${ }^{1}$ Department of Mechanical EngineeringMaharashtra Institute of Technology, Aurangabad, Maharashtra, India
}

${ }^{2}$ Department of Mechanical Engineering Maharashtra Institute of Technology, Aurangabad, Maharashtra, India 
Micro/millimeter sized suspended particles were used at the beginning but it creates some difficulties like clogging and blockage on the flow passage while trying to enhance the heat transfer. Nanotechnology is introduced to overcome those difficulties [1].The Chemical processing industries, Power stations, Nuclear reactors, Transportation industries, Electronic industries and Heating, Ventilation and Air Conditioning face challenge in meeting out the cooling demand for the past decennium. Therefore, an increase in efficiency of the heat exchanger through augmentation techniques has been developed. There are three broad classifications of heat transfer augmentation techniques. Passive techniques which do not require any external power such as treated surfaces, rough surfaces, extended surfaces, swirl flow devices, displaced enhancement devices, coiled tube, surface tension device, additives for liquids, and additives of gasses. Active techniques which require external power to expedite the desired flow modification for augmenting heat transfer such as mechanical aids, surface vibration, fluid vibration, electrostatic fields, injection, suction, and jet impingement. Compound heat transfer technique is the combination of any two or three techniques [2].

\subsection{The Use of Nanofluid}

Nanofluids are heat transfer fluids stably suspended with nanoparticles which having an average size below $100 \mathrm{~nm}$. Common fluids used for cooling are water, oil, and ethylene glycol. Nanofluids are known to exhibit excellent heat transfer capabilities when compared to traditional heat transfer fluids. At the beginning millimeter and micrometer sized particles were dispersed in liquids but this creates problems such as particle sedimentation, passage clogging, erosion and high pressure drop. Recent advancement in nanotechnology has allowed researches to utilize nanometer sized particles to reinvent the idea of mixing nanoparticle to base fluid [3]. A Nanofluid is a fluid containing nanometer sized particles called nanoparticles. These fluids are engineered colloidal suspensions of nanoparticles in a base fluid. The nanoparticles used in nanofluids are typically made of metals, oxides, carbides, or carbon nanotubes. The Common base fluids used for mixing the nanoparticles are water, ethylene glycol and oil [5]. Nanofluids have novel properties that make them potentially useful in many applications in heat transfer, including microelectronics, fuel cells, pharmaceutical processes, and hybrid, engine cooling/vehicle thermal management, domestic refrigerator, chiller, heat exchanger, in grinding, machining and in boiler flue gas temperature reduction. Nanofluids are primarily used as the coolant in heat transfer equipment such as heat exchangers, the electronic cooling system (such as a flat plate) and radiators. Heat transfer over flat plate has been analyzed by a lot of researchers.

\subsection{Nanofluid Preparation [3,4,27]}

Nanofluids are prepared by mixing nanoparticles with fluids is first done by Choi et al. [6]. Since then, there has been rapid development in the synthesis techniques for nanofluids. There are two techniques to prepare nanofluids for the study or research which are the single-step or the two step-methods. The common fluids in which the nanoparticles are added are water, oil, acetone, decene and ethylene glycol.

In Two-step process first nanoparticles are produced as a dry powder, typically by inert gas condensation. The second step involves dispersion of dry nanoparticles powder into a base fluid, like water, oil or ethylene glycol. The advantage of two-step process is that the inert gas condensation technique has been scaled up to commercial nanopowder production. A deficiency of this method is the tendency of nanopowder to agglomerate during storage and dispersion in the base fluids, particularly with heavier metallic nanoparticles. 
A single-step approach is emerging as a powerful method for growing nanostructures of different metals, semiconductors, non-metals and hybrid system. Laser ablation is another much sought, single-step technique that simultaneously makes and disperses nanoparticles directly in the base fluids. A variety of nanofluids has been prepared by laser ablation method by ablating solid metals, semiconductors, which are submerged in the base fluid. By creating the nanofluid in this way, stable nanofluids resulted without using any property-changing dispersants.

Mostly the two-step method is used to produce nanofluids. Through the common processes used to produce the nanopowders are inert gas-condensation, mechanical grinding, chemical vapor deposition, chemical precipitation, micro emulsion, thermal spray and spray pyrolysis. The major disadvantage of this process is that agglomeration can occur due to strong Vander Waals attractive forces. However, simple techniques such as ultrasonic agitation or the addition of surfactants can be used to minimize agglomeration and improve dispersion. However, caution should be placed in choosing the surfactant because the addition of surfactants can affect the heat transfer performance of the nanofluids at high temperatures.

Bhimani et al. [14] conducted an experimental study of heat transfer enhancement using water based nanofluids as a new coolant for car radiators. In this work the heat transfer coefficient in automobile, radiators are measured with two distinct working liquids i.e. pure water and water based nanofluid at different concentration and temperature. It is observed that the presence of $\mathrm{TiO}_{2}$ nanoparticle in water enhances the heat transfer rate of the automobile radiators and the degree of heat transfer enhancement depends on the amount of nanoparticle. The enhancement of heat transfer rate is by 40-45 percent at 1 volume percent of nanofluids.

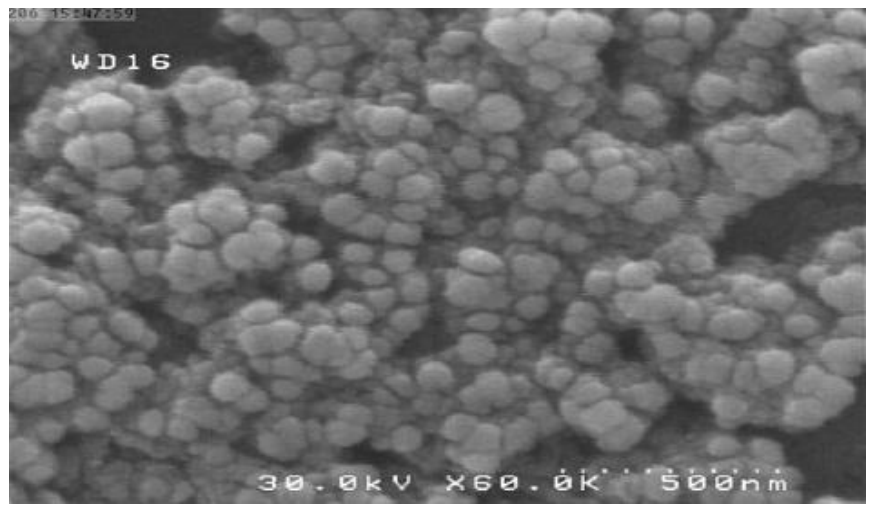

Figure 1. FESEM image of nanoparticles after dispersion [14]

Mukeshkumar et al. [2] conducted an experimental study on the experimental study on parallel and counter flow configuration of a shell and helically coiled tube heat exchanger using $\mathrm{Al}_{2} \mathrm{O}_{3} /$ water nanofluid. In this study the nanofluid $\mathrm{Al}_{2} \mathrm{O}_{3}$ at 0.4 percent and 0.8 percent particle volume concentration were prepared and characterized by using XRD and SEM. It is observed that the overall heat transfer coefficient of counter flow is 4-8 percent higher than that of parallel flow at 0.4 percent nanofluid. The overall heat transfer coefficient is 5-9 percent higher than that of parallel flow at 0.8 percent nanofluid and there is no much impact of changing flow direction on overall heat transfer coefficient. 


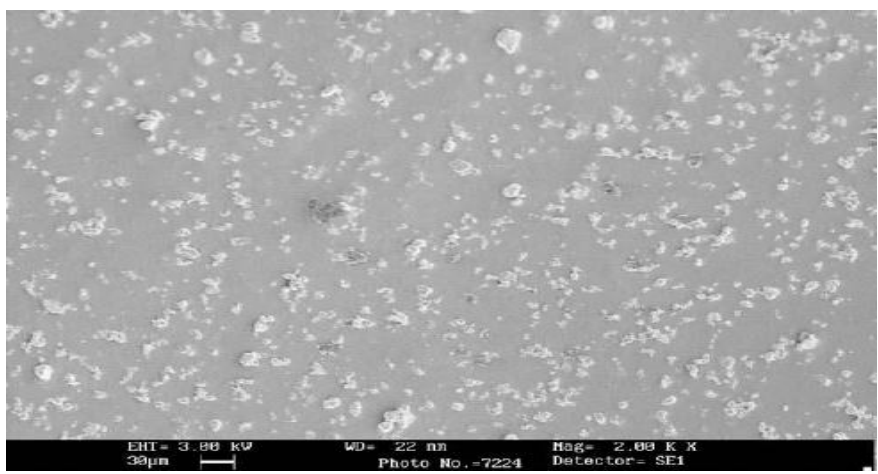

Figure 2. SEM image of $\mathrm{Al}_{2} \mathrm{O}_{3}$ nanoparticles [2]

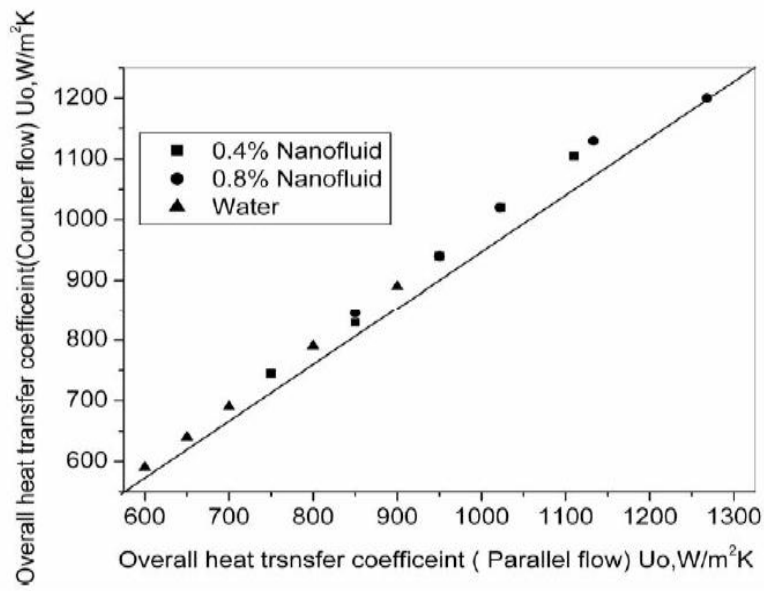

Figure 3. Comparison of overall heat transfer coefficient of counter and parallel flow configuration under laminar flow [2]

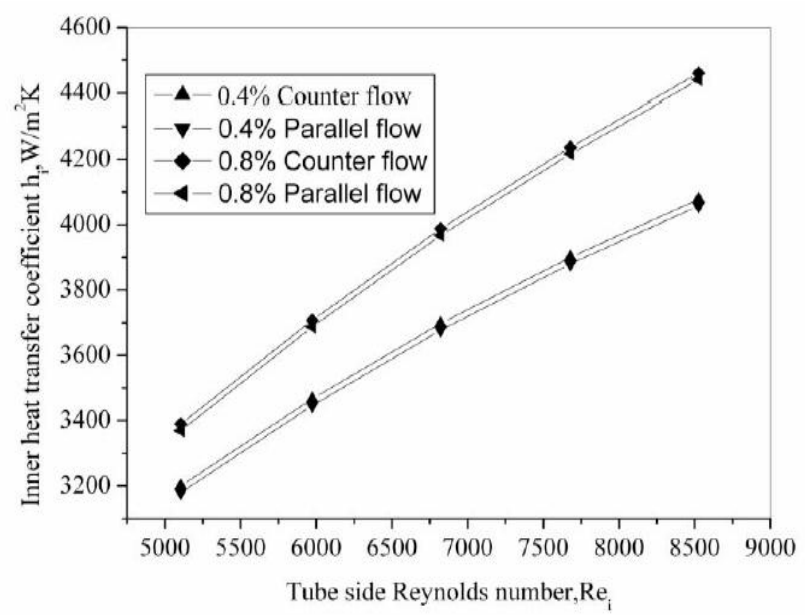

Figure 4. Variation of inner heat transfer coefficient with tube side Reynolds number [2]

Elias et al. [7] conducted an experimental and numerical study on an effect of nanoparticle shape on the heat transfer and thermodynamic performance of a shell and tube heat exchanger. In this 
study the effect of different nanoparticle shapes on heat transfer characteristics and thermodynamic performance of boehmite alumina $(\gamma-\mathrm{AlOOH})$-water/ethylene glycol nanofluid was analysed throughout. The effects of nanoparticle size were assumed negligible in this study. Best performance was for cylindrical shaped nanoparticle followed by bricks, blades, platelets and spherical shaped nanoparticles, respectively. Cylindrical shaped nanoparticle showed better performance in terms of thermal conductivity, heat transfer coefficients, and heat transfer rate.

Albadr et al. [8] conducted an experimental and numerical study on a heat transfer through the heat exchanger using $\mathrm{Al}_{2} \mathrm{O}_{3}$ nanofluid at different concentrations. In this study, the convective heat transfer performance and flow characteristics of $\mathrm{Al}_{2} \mathrm{O}_{3}$ nanofluid flowing in a horizontal shell and tube heat exchanger have been experimentally investigated. Experiments were carried out under turbulent conditions. It is observed that at the particle volume concentration of 2 percent the overall heat transfer coefficient is $700.242 \mathrm{~W} / \mathrm{m}^{2} \mathrm{~K}$ and for the water it is 399.15 $\mathrm{W} / \mathrm{m}^{2} \mathrm{~K}$ for a mass flow rate of $0.0125 \mathrm{l} / \mathrm{s}$ so the enhancement ratio of the overall heat transfer coefficient is 1.754 , this means the amount of the overall heat transfer coefficient of the nanofluid is 57 percent greater than that of distilled water.

Khedkar et al. [10] conducted an experimental and numerical study on a Heat transfer study on concentric tube heat exchanger using $\mathrm{TiO}_{2}$-water based nanofluid. In this work, experiments were carried out for a wide range of Reynolds number and nanoparticle volume concentrations. It is observed that the $\mathrm{TiO}_{2}$ is a promising nanoparticle for the enhancement of an overall convective heat transfer coefficients of water and the heat transfer characteristics of nanofluids improve with Reynolds number significantly as compared to base fluids.

Darzi et al. [11] conducted an experimental and numerical study on an experimental investigation of turbulent heat transfer and flow characteristics of $\mathrm{SiO}_{2}$ /water nanofluid within helically corrugated tubes. In this work, an experimental study performed to explore the effect of $\mathrm{SiO}_{2}$ nanoparticles in helically corrugated tubes. It is observed that increasing the corrugated height and lowering the corrugated pitch enhance the heat transfer.

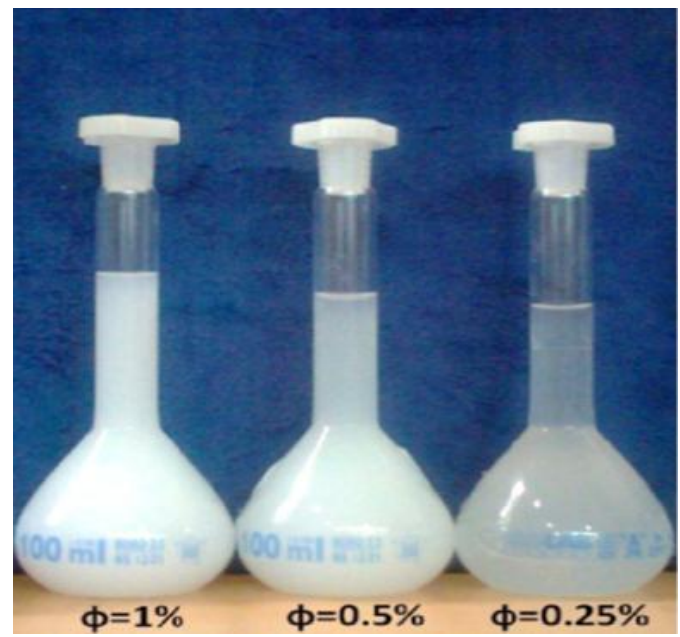

Figure 5. Sample of prepared nanofluids [12]

Huminic et al. [13] conducted an experimental and numerical study on a Heat transfer characteristics in double tube helical heat exchangers using nanofluids. A numerical study is carried out on the heat transfer behavior of nanofluids flowing through a counter-flow double tube helical heat exchanger under a laminar flow condition. $\mathrm{CuO} /$ water and $\mathrm{TiO}_{2} / \mathrm{water}$ 
nanofluids are used in this work to investigate the heat transfer characteristics. It is observed that the use of $\mathrm{CuO}$ and $\mathrm{TiO}_{2}$ nanoparticles as the dispersed in water can significantly enhance the convective heat transfer in the laminar flow regime, and the enhancement increases with Dean Number, as well as particle concentration level under the conditions of this work. Also, outlet water temperature increases with increasing particle concentration level from the inner tube.

Elsayed et al. [15] conducted an experiment on numerical investigation of turbulent flow heat transfer and pressure drop of $\mathrm{Al}_{2} \mathrm{O}_{3}$ / water nanofluid in helically coiled tubes. It is observed that using 5 percent volume fraction of $\mathrm{Al}_{2} \mathrm{O}_{3} /$ water nanofluids in helical coils increases the heat transfer coefficient by up to 60 percent of that for pure water.

Farajollahi et al. [16] conducted an experimental study on heat transfer of nanofluids in shell and tube heat exchanger. It is observed that the heat transfer characteristics of nanofluids improve with peclet number and it shows that addition of nanoparticles to the base fluid enhance the heat transfer performance and both nanofluids have the different optimum volume concentration in which the heat transfer characteristics showed the maximum enhancement.

Mohammed et al. [17] conducted an experimental study on heat transfer enhancement of nanofluids in a double pipe heat exchanger with louvered strip inserts and it is observed that the forward louvered strip arrangements can promote the heat transfer by approximately 350 percent to 400 percent at the highest slant angle of $30^{\circ}$ and pitch of $30 \mathrm{~mm}$ and the backward arrangement improve the heat transfer by approximately 367 percent to 411 percent.

Senthilraja et al. [18] conducted an experimental study on analysis of heat transfer coefficient of $\mathrm{CuO} /$ water nanofluid using double pipe heat exchanger. In this study, the nanofluid was prepared by dispersing $\mathrm{CuO}$ of $27 \mathrm{~mm}$ particles in deionized water. The result of this study shows that the convective heat transfer coefficient and nusselt number of nanofluids were increased compared to base fluid i.e. water.

Salimpour et al. [31] conducted an Experimental study on a shell and helical coil heat exchanger using cold and hot water for the shell and coil sides. In this study three different coils tested, varying in pipe diameter and pitch. The tube and shell side flow rates were measured as well as the inlet and outlet temperatures for both. It is observed that the fluid properties were evaluated at their mean temperature. The outer heat transfer coefficients were calculated using the Wilson Plot method. A total of 75 outer heat transfer coefficients calculated based upon five different shell side flow rates, leading to a total of 15 calculated inner heat transfer coefficients.

Lotfi et al. [4] conducted an Experimental study on the heat transfer enhancement of MWNTwater nanofluid in a shell and tube heat exchanger. Multi-walled carbon nanotubes were synthesized by the use of chemical vapor deposition (CVD) method over $\mathrm{Co}-\mathrm{Mo} / \mathrm{MgO}$ nanocatalyst. MWNTs then purified using a three-stage method consisting of oxidation, $\mathrm{HCl}$ treatment, and $\mathrm{HNO}_{3}$ treatment. To make the nanotubes hydrophilic and increase the stability of the nanofluid, $\mathrm{COOH}$ functional groups were inserted.

Jamshidi et al. [19] conducted the experimental analysis of heat transfer enhancement in the shell and helical tube heat exchangers. In this study, an experimental investigation is carried out to study the heat transfer characteristics in shell and helical tube heat exchangers it is observed that:

- $\quad$ By increasing the shell side flow rate, the Nusselt number increases.

- As coil pitch increases, tube side Nusselt number decreases and tube side flow rate affects this variation. By increasing coil pitch, shell side Nusselt number increases. Increasing coil pitch, increases overall heat transfer coefficient.

- In tube side, by increasing coil diameter, tube side Nusselt number and overall heat transfer coefficient increase and shell side Nusselt number decrease. 
Darzi et al. [12] conducted an experimental and numerical study on a Heat transfer and flow characteristics of $\mathrm{Al}_{2} \mathrm{O}_{3}$-water nanofluid in a double tube heat exchanger. In this study, the fully developed turbulent heat transfer, and the pressure drop behavior of $\gamma-\mathrm{Al}_{2} \mathrm{O}_{3}$ - water nanofluid in double tubes heat exchanger have experimentally investigated. It is observed that by increasing the concentration of nanofluid, the heat transfer and the pressure drop simultaneously increased. Meanwhile, the heat transfer rate and friction factor intensify at higher and lower Reynolds number, respectively and it is also observed that concluded that adding the nanoparticles to the base fluid has the better result at higher Reynolds number.

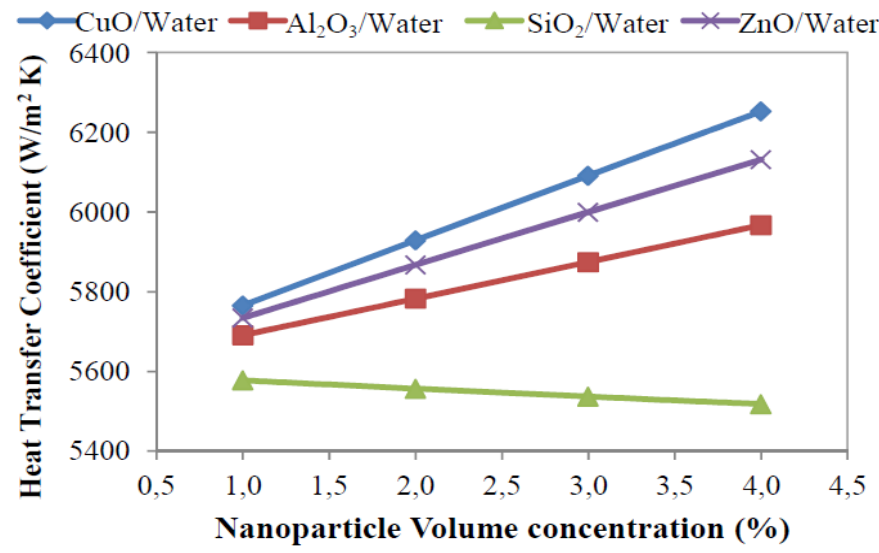

Figure 6. Variation of heat transfer coefficient with nanoparticles volume concentration for four different nanofluids flow inside the helical tube [1]

Table -I. Experimental Studies on Heat Transfer Coefficient of Nanofluids

\begin{tabular}{|c|c|c|c|c|}
\hline Author Name & Nanofluid Used & $\begin{array}{l}\text { Percent Volume } \\
\text { Concentration of } \\
\text { Nanofluid }\end{array}$ & Type of Heat Exchanger & $\begin{array}{l}\text { Enhancement in Heat Transfer } \\
\text { Coefficient }\end{array}$ \\
\hline $\begin{array}{l}\text { Mukeshkumar P.C } \\
\text { et al. [2] }\end{array}$ & $\begin{array}{l}\mathrm{Al}_{2} \mathrm{O}_{3} / \text { Water } \\
45-50 \mathrm{~nm}\end{array}$ & $\begin{array}{l}0.4 \text { Percent and } \\
0.8 \text { Percent }\end{array}$ & $\begin{array}{l}\text { Shell and helically coiled } \\
\text { heat exchanger }\end{array}$ & $\begin{array}{l}\text { 4-8 Percent Higher at } 0.4 \text { Percent } \\
\text { 5-9 Percent Higher at } 0.8 \text { Percent }\end{array}$ \\
\hline Elsayed et al. [15] & $\mathrm{Al}_{2} \mathrm{O}_{3} /$ Water & $\begin{array}{l}3 \text { Percent Volume } \\
\text { Fraction of } \\
\text { Nanofluid }\end{array}$ & Helically coiled tube & Increased by 60 Percent \\
\hline Elias et al. [7] & Water/Ethylene Glycol & 0 to 1 Percent & $\begin{array}{l}\text { Shell and tube heat } \\
\text { exchanger }\end{array}$ & $\begin{array}{l}\text { for Cylindrical Shape } 2.4 \text { Percent Higher } \\
\text { At } 1 \text { Percent }\end{array}$ \\
\hline Maddah et al.[20] & $\begin{array}{l}\mathrm{Al}_{2} \mathrm{O}_{3} / \text { Water } \\
20-22 \mathrm{~nm}\end{array}$ & 0.2 and 1 Percent & $\begin{array}{l}\text { Horizontal double pipe } \\
\text { heat exchanger }\end{array}$ & Increased by 12 to 52 Percent \\
\hline
\end{tabular}




\begin{tabular}{|c|c|c|c|c|}
\hline Bhimani et al.[14] & $\begin{array}{l}\mathrm{TiO}_{2} / \text { Water } \\
15 \mathrm{~nm}\end{array}$ & 0.1 to 1 Percent & Car radiators & $\begin{array}{l}\text { at } 1 \text { Percent heat transfer coefficient } \\
40-45 \text { Percent Increased }\end{array}$ \\
\hline Farajollahi et al.[16] & $\begin{array}{l}\mathrm{Al}_{2} \mathrm{O}_{3} / \text { Water } \\
\mathrm{TiO}_{2} / \text { Water } \\
\mathrm{TiO}_{2^{-}} 10 \mathrm{~nm}\end{array}$ & $\begin{array}{l}\mathrm{Al}_{2} \mathrm{O}_{3} / \text { Water- } 0.3 \\
\text { to } 2 \text { Percent } \\
\mathrm{TiO}_{2} / \text { Water } 0.15 \\
\text { to } 0.75 \text { Percent }\end{array}$ & $\begin{array}{l}\text { Shell and tube heat } \\
\text { exchanger }\end{array}$ & $\begin{array}{l}\text { Heat transfer coefficient of } \mathrm{Al}_{2} \mathrm{O}_{3} / \text { Water } \\
\text { occurs at } 0.5 \text { Percent about } 20 \text { Percent }\end{array}$ \\
\hline $\begin{array}{ll}\text { Huminic } & \text { and } \\
\text { Huminic [13] } & \end{array}$ & $\begin{array}{ll}\mathrm{CuO} / \text { Water } & \text { And } \\
\mathrm{TiO}_{2} / \text { Water } 24 \mathrm{~nm} & \end{array}$ & 0.5 to 3 Percent & $\begin{array}{l}\text { Double tube helical heat } \\
\text { exchanger }\end{array}$ & $\begin{array}{l}\text { at } 2 \text { Percent of } \mathrm{CuO} / \text { Water Increasing } 14 \\
\text { Percent }\end{array}$ \\
\hline Albadr et al. [8] & $\begin{array}{l}\mathrm{Al}_{2} \mathrm{O}_{3} / \text { Water } \\
30 \mathrm{~nm}\end{array}$ & 0.3 to 2 Percent & $\begin{array}{l}\text { Horizontal shell and tube } \\
\text { heat exchanger }\end{array}$ & $\begin{array}{l}\text { Heat transfer coefficient is } 57 \text { Percent } \\
\text { Increases }\end{array}$ \\
\hline $\begin{array}{l}\text { Senthilraja S.and } \\
\text { Vijaykumar [18] }\end{array}$ & $\begin{array}{l}\mathrm{CuO} / \text { Water } \\
27 \mathrm{~nm}\end{array}$ & $\begin{array}{l}0.1 \quad \text { and } \quad 0.3 \\
\text { Percent }\end{array}$ & $\begin{array}{l}\text { Double pipe heat } \\
\text { exchanger }\end{array}$ & $\begin{array}{l}\text { Greater with } 0.3 \text { Percent } \text { Volume } \\
\text { Concentration }\end{array}$ \\
\hline $\begin{array}{l}\text { Narrein and H.A. } \\
\text { mohammed [9] }\end{array}$ & $\begin{array}{l}\mathrm{Al}_{2} \mathrm{O}_{3}, \mathrm{CuO}, \mathrm{SiO}_{2}, \mathrm{ZnO} \\
\text { in (water, ethylene } \\
\text { glycol, engine oil). } 25 \text { to } \\
80 \mathrm{~nm}\end{array}$ & 1 to 4 percent & $\begin{array}{l}\text { Helically coiled tube heat } \\
\text { exchanger }\end{array}$ & $\begin{array}{l}\mathrm{SiO}_{2} \text { had the highest pressure drop. } \\
\text { Convective heat transfer tends to worsen } \\
\text { above } \\
2 \text { percent concentration due to the increase } \\
\text { in pressure drops in } \mathrm{CuO} \text {-water nanofluid. }\end{array}$ \\
\hline Darzi et al. [11] & $\begin{array}{l}\mathrm{SiO}_{2} / \text { water } \\
30 \mathrm{~nm}\end{array}$ & 0 to 1 percent & $\begin{array}{l}\text { Helically coiled tube heat } \\
\text { exchanger }\end{array}$ & $\begin{array}{l}\text { Increasing the corrugated height and } \\
\text { lowering the corrugated pitch enhance the } \\
\text { HTC. }\end{array}$ \\
\hline Khedkar et al.[10] & $\begin{array}{l}\mathrm{TiO}_{2} / \text { Water } \\
20 \mathrm{~nm}\end{array}$ & 2 and 3 percent & $\begin{array}{l}\text { Concentric tube heat } \\
\text { exchanger }\end{array}$ & $\begin{array}{l}\text { The overall heat transfer coefficient } \\
\text { increases with nanoparticle concentration. } \\
\text { The maximum enhancement of the overall } \\
\mathrm{HTC}_{\mathrm{T}} \mathrm{TiO}_{2} / \text { water nanofluids occurs at } 3 \\
\text { percent volume concentration. }\end{array}$ \\
\hline
\end{tabular}

Table- II. Experimental Studies on Friction Factor and Pressure Drop of Nanofluids

\begin{tabular}{|c|c|c|c|}
\hline Author Name & $\begin{array}{l}\text { Nanofluid Used with Particle Volume } \\
\text { Concentrations }\end{array}$ & Friction Factor & Pressure Drop \\
\hline Khairul et al. [1] & $\begin{array}{l}\mathrm{CuO} / \text { Water, } \mathrm{Al}_{2} \mathrm{O}_{3} / \text { Water, } \mathrm{ZnO} / \text { Water and } \\
\mathrm{SiO}_{2} / \text { Water } 1 \text { to } 4 \text { percent }\end{array}$ & $\mathrm{CuO}$ - friction factor reduces & $\begin{array}{l}\mathrm{CuO} \text { - Higher pressure drop } \\
\mathrm{SiO}_{2} \text { - lower pressure drop }\end{array}$ \\
\hline Kirubadurai et al. [5] & & $\begin{array}{l}\text { Friction factor increases with } \\
\text { increasing particle volume } \\
\text { concentrations. }\end{array}$ & $\begin{array}{l}\text { Concentration-s of particle increase } \\
\text { the pressure drop of nanofluid }\end{array}$ \\
\hline Albadr et al. [8] & $\begin{array}{l}\mathrm{Al}_{2} \mathrm{O}_{3} / \text { Water } \\
0.3 \text { to } 2 \text { Percent }\end{array}$ & $\begin{array}{l}\text { Increase in friction factor with } \\
\text { increase in particle volume } \\
\text { concentrations }\end{array}$ & Little decrease in pressure drop \\
\hline
\end{tabular}


Narrein and H.A $\mathrm{Al}_{2} \mathrm{O}_{3}, \mathrm{CuO}, \mathrm{SiO}_{2}, \mathrm{ZnO}$ in (water, ethylene Mohammed [9]

Darzi et al. [11]

Darzi et al.[12]

Maddah et al. [20]

Kannadasan et al. [28]

uO/water

0.1 and 0.2 percent

Jamshidi et al. [29] $\quad \mathrm{Al}_{2} \mathrm{O}_{3}$ /Water

1 and 3 percent
Friction factor increases with increasing particle volume concentrations.

Friction factor increases with increasing particle volume concentrations.

Friction factor increases with particle volume concentrations

Friction factor in double pipe heat exchanger is 1.03 to 4 and 1.4 to 2.8 times in plane tube heat exchanger

Friction factor at 0.1 and 0.2 percent of nanofluid is 7 and 21 percent compared with water

Increase in friction factor results in more pumping power

Friction factor increases with particle volume concentrations pressure drop increases $\mathrm{SiO}_{2}$ has highest pressure drop compare to $\mathrm{Al}_{2} \mathrm{O}_{3}, \mathrm{CuO}$ and $\mathrm{ZnO}$

Little reduction in pressure drop

Increasing particle volume concentrations

the pressure drop increases

Pressure drop increases with particle volume concentrations

Pressure drop increases

Pressure drop decreases as tube diameter increases

For calculating thermal conductivity, viscosity, density, and Specific heat of nanofluid following four equations is to be used [21-24]

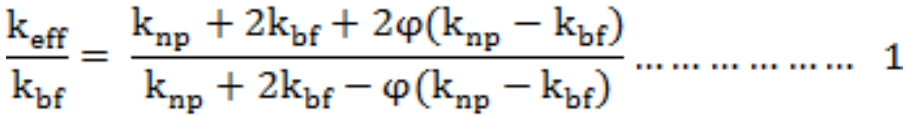

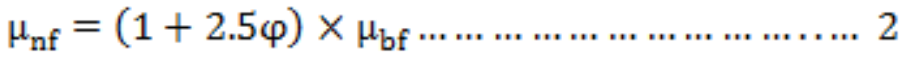

$$
\begin{aligned}
& \rho_{\mathrm{nf}}=(1-\varphi) \rho_{b f}+\varphi \rho_{\mathrm{np}} \ldots \ldots \ldots \ldots \ldots \ldots \ldots \ldots \ldots .3 \\
& C_{p . n f}=\frac{(1-\varphi)\left(\rho C_{p}\right)_{b f}+\left(\rho C_{p}\right)_{n p}}{\rho_{n f}} \ldots \ldots \ldots \ldots . \ldots
\end{aligned}
$$




\section{CONCLUSION}

In this present study, the review of enhancement in heat transfer rate using nanofluids of helically coiled tube heat exchanger is studied. The main focus of this study is to understand the concept of enhancement in heat transfer rate in helically coiled tube heat exchanger. After studies it is observed that the heat transfer rate mainly depends on the particle volume concentration of nanoparticles if the particle volume concentration is increased the heat transfer rate increases. Different nanoparticles are used by the authors with different shape and size and different particle volume concentration of nanoparticles. It is observed that the friction factor is 7 to 21 percent [28] increases by increasing the particle volume concentration of nanofluid due to increase in viscosity it also observed that increase in friction factor increases the pumping power and pumping power is also increases with increasing the particle volume concentration of nanofluid. If tube diameter of heat exchanger increases the pressure drop decreases and pressure drop is mainly depend on density if a density of nanofluid is decreased the pressure drop is also decreased.

Nomenclature

$\begin{array}{ll}\mathrm{D}_{\mathrm{H}} & \text { Average diameter of helix, } \mathrm{m} \\ \mathrm{D}_{\mathrm{S}} & \text { Shell inside diameter, } \mathrm{m} \\ \mathrm{d}_{\mathrm{o}} & \text { Tube outside diameter, } \mathrm{m} \\ \mathrm{d}_{\mathrm{i}} & \text { Tube inside diameter, } \mathrm{m} \\ \mathrm{h}_{\mathrm{i}} & \text { Tube side heat transfer coefficient, } \mathrm{W} /\left(\mathrm{m}^{2}\right)\left({ }^{\mathrm{o}} \mathrm{c}\right) \\ \mathrm{h}_{\mathrm{o}} & \text { Shell side heat transfer coefficient, } \mathrm{W} /\left(\mathrm{m}^{2}\right)\left({ }^{\mathrm{o}} \mathrm{c}\right) \\ \mathrm{U}_{\mathrm{o}} & \text { Overall heat transfer coefficient, } \mathrm{W} /\left(\mathrm{m}^{2}\right)\left({ }^{\mathrm{o}} \mathrm{c}\right) \\ \mathrm{q} & \text { Heat transfer rate, }(\mathrm{W}) \\ \mathrm{A}_{\mathrm{o}} & \text { Outside surface area of coiled tube, }\left(\mathrm{m}^{2}\right) \\ \Delta \mathrm{T}_{\mathrm{LM}} & \text { Log mean temperature difference, }\left({ }^{\mathrm{o}} \mathrm{c}\right) \\ \mathrm{h} & \text { Heat transfer coefficient, } \mathrm{W} /\left(\mathrm{m}^{2}\right)\left({ }^{\mathrm{o}} \mathrm{c}\right) \\ \mathrm{A} & \left.\text { Peripheral area, (m }{ }^{2}\right) \\ \dot{\mathrm{m}}_{\mathrm{c}} & \text { Mass flow rate of cold fluid, }(\mathrm{Kg} / \mathrm{s}) \\ \dot{\mathrm{m}}_{\mathrm{h}} & \text { Mass flow rate of hot fluid, }(\mathrm{Kg} / \mathrm{s}) \\ \mathrm{C}_{\mathrm{p}, \mathrm{h}} & \text { Specific heat of hot fluid, }\left(\mathrm{J} / \mathrm{Kg}{ }^{\mathrm{o}} \mathrm{c}\right) \\ \mathrm{C}_{\mathrm{p}, \mathrm{c}} & \text { Specific heat of cold fluid, }\left(\mathrm{J} / \mathrm{Kg}{ }^{\mathrm{o}} \mathrm{c}\right) \\ \mathrm{K} & \text { Thermal conductivity, }\left(\mathrm{W} / \mathrm{m}^{\mathrm{o}} \mathrm{c}\right) \\ & \end{array}$

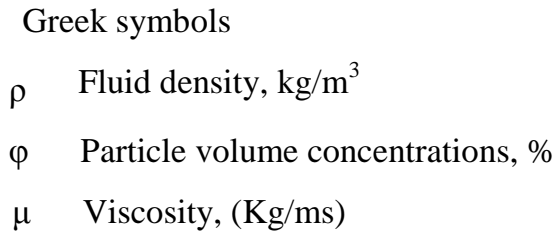


[4] Roghayeh Lotfi, Ali Morad Rashidi, Azadeh Amrollahi, "Experimental study on the heat transfer enhancement of MWNT-water nanofluid in a shell and tube heat exchanger," International Communications in Heat and Mass Transfer, vol. 39, pp. 108-111, 2012.

[5] B. Kirubadurai, P.Selvan, V.Vijayakumar, M.Karthik, "Heat transfer enhancement of nano fluids -A review," International Journal of Research in Engineering and Technology, Volume 03 Issue 07, eISSN: 2319-1163, pISSN: 2321-7308, 2014.

[6] S.U.S. Choi, D.A. Signer, H.P. Wang, "Enhancing thermal conductivity of fluids with nanoparticles," Developments Applications of Non-Newtonian Flows, FED-Vol. 231/MD, 66, pp. 99-105, 1995.

[7] M.M. Elias, M.Miqdad, I.M.Mahbubul, R.Saidur, M. Kamalisarvestani, M.R. Sohel, Arif Hepbasli, N.A. Rahim, M.A. Amalina, "Effect of nanoparticle shape on the heat transfer and thermodynamic performance of a shell and tube heat exchanger," International Communications in Heat and Mass Transfer, vol. 44, pp. 93-99, 2013.

[8] Jaafar Albadr, Satinder Tayal, Mushtaq Alasadi, "Heat transfer through heat exchanger using $\mathrm{Al}_{2} \mathrm{O}_{3}$ nanofluid at different concentrations," Case Studies in Thermal Engineering, vol. 1, pp. 38-44, 2013.

[9] K. Narrein, H.A. Mohammed, "Influence of nanofluids and rotation on helically coiled tube heat exchanger Performance," Thermochimica Acta 564, pp. 13-23, 2013.

[10] R. S. Khedkar, S. S. Sonawane, K. L. Wasewar, "Heat transfer study on concentric tube heat exchanger using $\mathrm{TiO}_{2}$-water based nanofluid," International Communications in Heat and Mass Transfer, vol. 57, pp. 163-169, 2014.

[11] A. A. Rabienataj Darzi, Mousa Farhadi, Kurosh Sedighi, Rouzbeh Shafaghat, Kaveh Zabihi, "Experimental investigation of turbulent heat transfer and flow characteristics of $\mathrm{SiO}_{2}$ /water nanofluid within helically corrugated tubes," International Communications in Heat and Mass Transfer, vol. 39, pp. 1425-1434, 2012.

[12] A. A. Rabienataj Darzi, Mousa Farhadi, Kurosh Sedighi, "Heat transfer and flow characteristics of $\mathrm{Al}_{2} \mathrm{O}_{3}-$ water nanofluid in a double tube heat exchanger," International Communications in Heat and Mass Transfer, vol. 47, pp. 105-112, 2013.

[13] Gabriela Huminic, Angel Huminic, "Heat transfer characteristics in double tube helical heat exchangers using nanofluids,” International Journal of Heat and Mass Transfer, vol. 54, pp. 4280-4287, 2011.

[14] V. L. Bhimani, Dr. P. P. Rathod, Prof. A. S. Sorathiya, "Experimental study of heat transfer enhancement using water based nanofluids as a new coolant for car radiators," International Journal of Emerging Technology and Advanced Engineering Volume 3, Issue 6, June 2013.

[15] Ahmed Elsayed, Raya K. Al-dadah, Saad Mahmoud and Ahmed Rezk, "Numerical investigation of turbulent flow heat transfer and pressure drop of $\mathrm{Al}_{2} \mathrm{O}_{3} /$ water nanofluid in helically coiled tubes," International Journal of Low-Carbon Technologies, pp. 1-8, 2014.

[16] B. Farajollahi, S.Gh. Etemad, M. Hojjat, "Heat transfer of nanofluids in a shell and tube heat exchanger," International Journal of Heat and Mass Transfer, vol. 53, pp. 12-17, 2010.

[17] H. A. Mohammed, Husam A. Hasan, M.A. Wahid, "Heat transfer enhancement of nanofluids in a double pipe heat exchanger with louvered strip inserts," International Communications in Heat and Mass Transfer, vol. 40, pp. 36-46, 2013.

[18] S. Senthilraja and KCK. Vijayakumar, "Analysis of heat transfer coefficient of $\mathrm{CuO} / \mathrm{Water}$ nanofluid using double pipe heat exchanger," International Journal of Engineering Research and Technology, Volume 6, Number 5, pp. 675-680, 2013.

[19] N. Jamshidi, M. Farhadi, D.D. Ganji, K. Sedighi, "Experimental analysis of heat transfer enhancement in shell and helical tube heat exchangers," Applied Thermal Engineering, vol. 51, pp. 644-652, 2013.

[20] Heydar Maddah, Mostafa Alizadeh, Nahid Ghasemi, Sharifah Rafidah Wan Alwi, "Experimental study of $\mathrm{Al}_{2} \mathrm{O}_{3}$ /water nanofluid turbulent heat transfer enhancement in the horizontal double pipes fitted with modified twisted tapes," International Journal of Heat and Mass Transfer, vol. 78, pp. 1042-1054, 2014.

[21] J.C. Maxwell, "A treatise on electricity and magnetism," Clarendon Press, 1881.

[22] A. Einstein, "Investigation on the theory of brownian motion," Dover, New York, 1956.

[23] Gherasim, G. Roy, C.T. Nguyen, D. Vo-Ngoc, "Experimental investigation of nanofluids in confined laminar radial flows," International Journal of Science, vol. 48, pp. 1486-1493, 2009.

[24] Y. Xuan, W. Roetzel, "Conceptions for heat transfer correlation of nanofluids," International Journal of Heat Mass Transfer, vol. 43, pp. 3701-3707, 2000.

[25] Sadik Kakac, Hongton Liu, "Heat exchangers selection, rating and thermal design," CRC press LLC, 2002.

[26] Ramachandra K. Patil, B.W. Shende, Prasanta K. Ghosh, "Designing a helical coil heat exchanger," Chemical Engineering, 1982. 
[27] Jagdeep M. Kshirsagar, Ramakant Shrivastava, "Review of the influence of nanoparticles on thermal conductivity, nucleate pool boiling and critical heat flux" Heat Mass Transfer, vol. 51, pp. 381-398, 2015.

[28] N. Kannadasan, K. Ramanathan, S. Suresh, "Comparison of heat transfer and pressure drop in horizontal and vertical helically coiled heat exchanger with $\mathrm{CuO}$ /water based nano fluids," Experimental Thermal and Fluid Science, vol. 42, pp. 64-70, 2012.

[29] Naghmeh Jamshidi, Mousa Farhadi, Kurosh Sedighi, Davood Domeiry Ganji, "Optimization of design parameters for nanofluids flowing inside helical coils," International Communications in Heat and Mass Transfer, vol. 39, pp. 311-317, 2012.

[30] Ashish K. Pandey, P. K. Mishra, K. K. Srivastava, "A critical review on fluid flow and heat transfer in circular helically coiled tube heat exchanger for laminar flow," International journal of engineering and science research, vol-4, issue-7, pp.436-445.

[31] M.R. Salimpour, "Heat transfer coefficients of shell and coiled tube heat exchangers," Experimental Thermal and Fluid Science, vol. 33, pp. 203-207, 2009. 